\title{
Regional Dimensions of Development of Sri Lanka
}

\section{R.J.M. Uduporuwa}

Department of Social Sciences, Sabaragamuwa University of Sri Lanka, P.O. Box 02, Belihuloya.

\begin{abstract}
This article examines the present situation of regional dimensions of development of Sri Lanka. In this respect, this study was carried out by employing several indicators of development. It can be clearly observed that, development strategies implemented by Sri Lanka within the past fifty years have not successfully contributed to reduce the socioeconomic disparities in Sri Lanka. Economic development, physical and social infrastructure facilities and urban growth etc. have distributed unevenly among nine provinces since1950s. The most functionally dynamic core region in the country lies in Western Province and most of the economic activities take place within this region. As a result, most of the other areas have become economically backward. Therefore, unequal development of regions called "provinces" is a problem throughout the history of Sri Lanka.

Key Words - Development, Regional Dimensions, Regional Disparities, Regional Development
\end{abstract}

\section{Introduction: Regional Approach in Development}

The term "Regional Development" can be understood as a process pertaining to a particular part of a country called "region". According to Glasson,

it can be seen as the process of development in a particular area or a region. It is often used in a relative context, comparing problem region with the prosperous regions or with the national context, on the basis of socio-economic indicators. It can be used in an absolute context also "the development within a particular region". Regional planning in its various forms is used to attempt the development of a region (Glasson, 1974).

Friedmann defines regional development as

the incidence of economic growth. It is ultimately the result of the location of economic activities in response to different regional attractions. Shifts in the location pattern have direct repercussions as income, employment and welfare. Since spatial organization is a function of activity and interaction pattern, regional development is simply an expression of these patterns (Friedmann, 1970).

Accordingly, he has emphasized that regional development involves a number of interrelated process including economic, social and political process within the spatial framework. Further he emphasized "economic growth" is the 
fundamental phenomenon which leads the regional development. He believes that ,

where the economic growth is sustained over long periods its incidence, works towards a progressive integration of the space economy (Friedmann, 1970).

In the Sri Lankan context, Sri Lanka still does not have a system of "regions" delineated for development purposes. It is the administrative districts that have been used as units for planning, coordinating and implementing development activities and central government policies at sub national level. The Provincial Councils established in 1987 were created for the first time as an intermediate layer of government with considerable development powers. According to this, at present Sri Lanka is divided into two levels in terms of development planning purposes as follows.

1. Sub national levels

11. Local levels
$=$ Provinces (Regional development planning)

$=$ Districts (Local level planning)

These subdivisions are based on the administrative status. The regional development planning of Sri Lanka is definitely at sub national level (Abeygunawardane, 1987). Thus, provinces involves as "regions" in the regional development planning in Sri Lanka. However, many academics and researchers have questioned the suitability of present provinces as appropriate territorial units for promoting socio-economic development. These provinces have been created by the rulers for the purpose of political and administrative control of the country. Therefore, these areas are not geo-economic development regions that have been demarcated based on the advantages of different regions and the socioeconomic and geographical realities (Goonarathna, 2001).

\section{A Historical Perspective of Development of Sri Lanka}

Just about 2000 years ago Sri Lanka has developed through hydro paddy-culture civilization in the Dry Zone. This development was possible in a large part of the country because of the highly developed irrigation system. This irrigation system gave rise to cities, architecture and social system in Sri Lanka. During this period of hydraulic civilization the settlement pattern spread along the river valleys in the northern plain and southeastern low lands of the Dry Zone. These were politically organized as kingdoms of Rajarata centered at Anuradhapura as the first capital city (300-1017 B.C) and the kingdom of Ruhuna with Magama as the capital. Dry Zone areas were developed under this civilization while most of the other areas of the Wet Zone were covered by forests.

Early in the $16^{\text {th }}$ century the European colonial era began in Sri Lanka with the arrival of the Portuguese (1505-1658) and Dutch (1658-1796). Under the Portuguese and Dutch rules the traditional system of settlements and associated socio-economic setting of Sri Lanka started to decline. During this period settlements and trading functions became prominent along the coastal areas in the South-West Wet Zone. As a result, irrigation based agriculture gave place to rain fed crops and Southwest low land became populated. After the Portuguese, Dutch and British ruled the whole country from the early nineteenth century (1815) until independence. 
European colonial powers changed the traditional agricultural economy and associated social system in Sri Lanka. They introduced plantation agriculture and it brought many changes in the socio-economic setting in Sri Lanka. The introduction of the plantation crops transformed the peasant agricultural economy into an export-import economy with a "dualistic agricultural structure".

The evaluation of the so-called "core periphery pattern" is one of the most significant issues of the plantation system. Under the British control Colombo was selected as the premier port and the city in the island and trading, administrative and service functions were strongly concentrated in Colombo from the early days of British rule to independence. Development of the KandyColombo road and railway as the main supply and export route into the plantation areas greatly led to the rapid development of the Colombo city. To day, Colombo with relatively high degree of socio-economic development has become the core region dominating the settlement hierarchy demographically and functionally in Sri Lanka.

\section{Regional Development Efforts in Sri Lanka}

After political independence in 1948 Sri Lanka has made some efforts to promote the socio-economic conditions of the rural people which have been neglected by the colonial rulers. Governments which came to power after independence paid attention to mainly national planning as the major instrument of development. Therefore, those governments implemented several national plans such as the Ten Year Plan in 1959, the Five Year Plan in 1970 and Public Investment in 1983-1987 which emphasized all island spatial sectoral development. All these programs, operated at national level and there were some attempts which implied certain type of regional development. These attempts can be divided mainly into two types as administrative decentralization of government functions and development programs.

Even before independence Sri Lanka had a decentralized administrative system up to certain extent to facilitate the central government implementing its functions of the regional level. Under this system District Coordinating Committees and the Divisional Coordinating Committees were established at district level and divisional level in 1954 to facilitate this system.

After 1970 the concept of regional development took its place in the country's development agenda. Therefore, regional development planning as a form of formalized planning came after 1970. After 1970 government established a new administrative system to accelerate the implementation of development activities at sub national level. In 1971 a Regional Development Division, in 1973 District Political Authority System, in 1978 District Ministry System, in 1980 the District Development Councils and in 1987 the Provincial Councils were established to decentralize the governmental functions. Although this institutional setup supported the implementation of sectoral development programs of the government, these programs were not region-specific (Dangalle, 2002).

Since $1930 \mathrm{~s}$ the national leadership launched several development programs to improve the living standard of the people of the country. The major development program that had been in operation in the early 1930s was the colonization of Sri Lanka's Dry Zone. This program comprised several components such as agricultural development, land settlements and provision of irrigation and food production. In addition, several specific geographical areas especially, river 
basins in the Dry Zone such as Gal Oya in1950 s, Kala Oya and Walawe Ganga in 1960 s were developed.

The government which, came to power 1977 paid high attention to regional development implementing several projects. They adopted a liberalized economic policy and favored the growth oriented development approach. Under this economic policy the government launched three major projects to achieve regional development. Those leads projects were the Greater Colombo Urban Development Project, Free Trade Zones Project, the Mahawali Development Project and the One Million Housing Project. The first two were in the Colombo Metropolitan Region and the third was in the North Central Province. One Million Housing Projects was an island wide program focusing on the poor in both urban and rural areas. After that Integrated Rural Development Projects were introduced in 1978 to deal with the problem of the rural sector that was not addressed by the above lead projects. These programs were launched at district level. Under these programs the government has decentralized development activities and decision-making process at district level. Industrial Estates were the third lead project implemented by the government. The Government decentralized industries as a means of generation of jobs in the rural areas. Under this program industrial estates were established in different parts of the country. At the same time, the establishment of garment factories in rural locations also provided jobs to the rural population.

In addition, the development of the Southern Province of Sri Lanka is also an important program implemented recently by the government. The government which came in to power in 1994 decided to revitalize the Southern Development Program. The major objective of this program was to make optimum use of the resources in the area. It covered Southern Districts of Galle, Matara and Hambantota.

\section{Inter-Regional Disparities in Present Development}

\section{Physical and Demographic Variations}

According to the various sources, disparities in development between regions are well marked to day in Sri Lanka (UNDP, 1998, Karunanayake, 2001, Dangalle, 2005). Though, various kinds of development strategies have been implemented aiming at regional development, Sri Lanka is still experiencing increasing disparities and widening income inequalities between regions. Economic development, physical and social infrastructure are unevenly spread in the geographical space. The most developed core region in the country lies in the Western Province. Most of the economic activities such as industry, trade, commerce and services take place within this region. All towns in the country are connected to Colombo city directly rather than other regional centers. As a result, regional disparities exist in most of the remaining areas in the country.

Table1 shows the variations in physical and demographic situation of nine provinces of Sri Lanka. These provinces show entirely different pictures in terms of both the land areas and population. The land extent of these nine provinces varies from $6 \%$ to $15.5 \%$ and population from 1.1 million to 5.3 million. Population density also varies among nine provinces. 
Though the Western Province is the smallest district, it contains the largest proportion of population of the country. Presently, it contains over 5 million out of the 18 million of the total population in Sri Lanka. It is the highly congested area having $28 \%$ of the total population in Sri Lanka. The other $71 \%$ of the population spread unevenly in the other 8 provinces. Though other provinces have high percentage of land extent, these provinces contain a smaller proportion of the population.

North Central is the largest province containing the smallest proportion of the total population. Although Central, Southern and Sabaragamuwa Provinces are relatively small in terms of the land extent these provinces contain considerable proportion of the population. Socio-economic development of these provinces also varies province to province. This existing gap in development between provinces is an effect of many causes.

Table 1 Provinces of Sri Lanka

\begin{tabular}{|c|c|c|c|}
\hline $\begin{array}{l}\text { Name of the } \\
\text { Province }\end{array}$ & $\begin{array}{l}\text { Districts } \\
\text { included }\end{array}$ & $\begin{array}{l}\text { Percentage of } \\
\text { total land extent }\end{array}$ & $\begin{array}{c}\text { Population (Million) } \\
2001\end{array}$ \\
\hline \multirow[t]{3}{*}{ Western } & Colombo & 6 & 5.3 \\
\hline & Gampaha & & \\
\hline & Kaluthara & & \\
\hline \multirow[t]{3}{*}{ Central } & Kandy & 8.5 & 2.4 \\
\hline & Matale & & \\
\hline & Nuwaraeliya & & \\
\hline \multirow[t]{3}{*}{ Southern } & Matara & 9 & 2.2 \\
\hline & Galle & & \\
\hline & Hambantota & & \\
\hline \multirow[t]{5}{*}{ Northern } & Jaffna & 13 & * \\
\hline & Mannar & & \\
\hline & Vauoniya & & \\
\hline & Mullaitivu & & \\
\hline & Killinochchi & & \\
\hline \multirow[t]{3}{*}{ Eastern } & Batticallo & 15 & * \\
\hline & Ampara & & \\
\hline & Trincomalle & & \\
\hline \multirow[t]{2}{*}{ North Western } & Kurunagala & 12 & 2.1 \\
\hline & Puttalam & & \\
\hline \multirow[t]{2}{*}{ North Central } & Anuradhapura & 15.5 & 1.1 \\
\hline & Polonnaruwa & & \\
\hline \multirow[t]{2}{*}{ Uva } & Badulla & 13 & 1.1 \\
\hline & Monaragala & & \\
\hline \multirow[t]{2}{*}{ Sabaragamuwa } & Rathnapura & 8 & 1.7 \\
\hline & Kegalle & & \\
\hline
\end{tabular}

* No data available

Source: - Department of Census and Statistics, 2002 


\section{Socio-Economic Variations}

According to historical reports and evidences many regions, which are backward today, had maintained prosperous economies during the ancient times. This agricultural self-sustaining economic system enabled to sustain a large proportion of the country. With the introduction of plantation agriculture the traditional economy collapsed and big disparities have been created among regions economically, socially and spatially. Ultimately this situation caused imbalances in the spatial structure of the country.

Presently, high concentration of population, industries and employment in the Colombo Metropolitan Region has become a major problem of the economic space in Sri Lanka. Therefore, dominance of the Colombo Metropolitan Region is the main issue showing the spatial imbalance in development. As Karunanayake has pointed out that "the dominance of the core region has led to the so called core-periphery dichotomy" (Karunanayake 2001). Economic policies after1978 is major factor that supported the polarized development in the Western Province. This situation has created a dualistic pattern of economic growth and has widened the core-periphery differentials in the country. This implies that as expected by the government the benefits of the growth concentrated around the Colombo Metropolitan Region have not been spread to other regions of the country. Ultimately earlier city primacy of the city of Colombo has been superseded by the regional primacy (Goonarathna, 2001).

Income gap between the CMR and the other regions has become an important indicator which shows inter-regional economic disparity. Although the GDP per capita has increased in all the provinces, during the last 2 decades the gap between the CMR and other regions has increased. The GDP per capita ratio for the Colombo Metropolitan Region and other provinces stood at 1:0.62 in 1990 worsened to 1:0.59 in 1995. In 1995 ratio for the Southern Province stood at 1:0.44. It was $1: 0.48$ for the Uva province and 1:0.44 for the Sabaragamuwa Province (UNDP, 1998). It implies that, income has become an important factor, which determines the spatial development of a region.

Differential economic growth rates are the main reason that support to widen the economic gap among regions. Economic growth rate in the Colombo Metropolitan Region between 1992 and 1995 was $7 \%$ while most of other regions it was $4 \%$. High concentration of economic activities is the major reason for high growth rate of the Colombo Metropolitan Region. For instance, manufacturing industry at present, accounts for over $72 \%$ while service sector accounts for $46 \%$ in the Colombo Metropolitan Region (UNDP, 1998).

The important point that needs an attention is the weakening of rural economy due to excessive growth of Colombo Metropolitan Region. During the last two decades there is a decline in project grants and fiscal subsidies to the other provinces (Karunanayeka, 2001). On the other hand the problem of low prices for agricultural products has further weakened the rural economy. As a result, educated and more dynamic people as well as savings and surplus labor are pushed to the cities. Ultimately, core or large cities advance in development while peripheral areas become economically backward. 


\section{Urban Growth}

Uneven urban growth is another important factor that shows the regional imbalance in Sri Lanka. Urban growth in Sri Lanka was mainly the outcome of the colonial administration and its economic interest. Most of the urban centers are located raw material supply routes that are linked to the main administrative centers in Sri Lanka. However, even today it is impossible to identify a change of distribution pattern of present urban centers. Most of the urban centers are located in the Wet Zone which corresponds to the South Western quadrant of the country comprising about $3 / 4$ of the total urban population. Large concentration is in the city of Colombo and around it. Therefore, the main urban cluster of the country is in the Colombo District with the polarization of Colombo city. After independence also this nature of the distribution pattern has no changes.

It is obvious that significant differences exist in the number, size, growth rates, and the level of urbanization among provinces of the country. According to the Table 2, except Western Province, all the other provinces are still experiencing slow urban growth and low level of urbanization. Policies implemented by the government after the independence had a more positive impact on urban growth of Western Province. Urban-based lead projects such as the urban development and housing programs and the establishment of the free trade zones in the Greater Economic Commission Area have increased towns of the Western Province. Expansion in public and private sector investments within a short period (1977-1981) and generation of more employment opportunities in the Western Province led to a faster growth of towns attracting more rural-urban migrants. Considering this situation Deheragoda et al (1992) and Wanasinghe (2001) have pointed out geographical coverage of lower order central places that can accelerate the rural economy in interior of the country is inadequate.

Table-2

Urban Growth and Urbanization of Sri Lanka by Provinces 1963-2001

\begin{tabular}{|l|c|c|c|c|c|c|c|c|}
\hline \multirow{2}{*}{ Province } & \multicolumn{2}{|c|}{1963} & \multicolumn{2}{c|}{1971} & \multicolumn{2}{c|}{1981} & \multicolumn{2}{c|}{2001} \\
\cline { 2 - 9 } & $\begin{array}{c}\text { Level of } \\
\text { urbani } \\
\text { zation }\end{array}$ & $\begin{array}{c}\text { No. of } \\
\text { towns }\end{array}$ & $\begin{array}{c}\text { Level of } \\
\text { urbani } \\
\text { zation }\end{array}$ & $\begin{array}{c}\text { No. of } \\
\text { towns }\end{array}$ & $\begin{array}{c}\text { Level of } \\
\text { urbani } \\
\text { zation }\end{array}$ & $\begin{array}{c}\text { No. of } \\
\text { towns }\end{array}$ & $\begin{array}{c}\text { Level of } \\
\text { urbani } \\
\text { zation }\end{array}$ & $\begin{array}{c}\text { No. of } \\
\text { towns }\end{array}$ \\
\hline Western & 40.5 & 38 & 47.9 & 38 & 46.56 & 38 & 30.5 & 17 \\
\hline Central & 10.2 & 16 & 10.6 & 15 & 11.1 & 15 & 9.8 & 9 \\
\hline Southern & 14.8 & 19 & 15.4 & 19 & 14.9 & 19 & 8.6 & 6 \\
\hline Northern & 23.1 & 10 & 42 & 10 & 28 & 10 & $*$ & $*$ \\
\hline Eastern & 20.6 & 16 & 24 & 16 & 22 & 16 & $*$ & 2 \\
\hline $\begin{array}{l}\text { North } \\
\text { Central }\end{array}$ & 9.6 & 4 & 9.9 & 4 & 7.3 & 4 & 5.1 & 1 \\
\hline $\begin{array}{l}\text { North } \\
\text { Western }\end{array}$ & 5.9 & 12 & 6.7 & 12 & 6.2 & 12 & 4.6 & 4 \\
\hline Uva & 6.8 & 8 & 6.9 & 8 & 6.2 & 8 & 4.5 & 3 \\
\hline $\begin{array}{l}\text { Sabaraga } \\
\text { muwa }\end{array}$ & $\mathbf{3 . 8}$ & $\mathbf{1 2}$ & $\mathbf{7 . 1}$ & $\mathbf{1 2}$ & $\mathbf{7 . 6}$ & $\mathbf{1 2}$ & $\mathbf{4 . 2}$ & $\mathbf{3}$ \\
\hline $\begin{array}{l}\text { Sri Lanka } \\
\text { * }\end{array}$ & $\mathbf{1 9 . 1}$ & $\mathbf{1 3 5}$ & $\mathbf{2 2 . 4}$ & $\mathbf{1 3 4}$ & $\mathbf{2 1 . 5}$ & $\mathbf{1 3 4}$ & $\mathbf{1 4 . 6}$ & $\mathbf{4 5}$ \\
\hline
\end{tabular}

${ }^{\star}$ No data available

Source: - Department of Census and Statistics. 


\section{Causes for Regional Disparities}

\section{Economic Growth}

According to the Table 3 majority of Gross Domestic Product (GDP) comes from the Western Province while the Northern Province represents the lowest. Six provinces contribute less than $10 \%$ to the national economy. This indicator clearly shows the regional variation in economic development in the country.

Table 3

\section{Regional Breakdown of GDP in Sri Lanka}

\begin{tabular}{|l|c|c|c|}
\hline \multirow{2}{*}{ Province } & \multicolumn{2}{|c|}{ Shares of GDP (\%) } & Growth rate of GDP \\
\cline { 2 - 4 } & 1990 & 1995 & $(\%)$ \\
\hline Western & 41.4 & 43.3 & 6.4 \\
\hline Central & 11.3 & 11.1 & 5.0 \\
\hline Southern & 9.5 & 9.7 & 6.1 \\
\hline North western & 10.8 & 10.3 & 4.3 \\
\hline North Central & 5.2 & 6.4 & 9.9 \\
\hline Uva & 5.6 & 5.1 & 3.5 \\
\hline Sabaragamuwa & 7.7 & 7.6 & 5.3 \\
\hline Northern & 4.4 & 2.5 & -6.2 \\
\hline Eastern & 4.0 & 3.9 & 5.0 \\
\hline
\end{tabular}

Source: - National Human Development Report, 1998

There is a wide gap in growth of GDP per capita in provinces also. According to the table during the period of 1990 to 1995 North Central Province has recorded the highest value in terms of growth rate of GDP per capita while all the other provinces have relatively slow growth rate.

The industrial sector in a country plays a major role in the regional economic development. In Sri Lanka, there is a wide gap in distribution of industrial enterprises too. According to Table 4 over $80 \%$ of industrial enterprises are concentrated in the Western Province while other provinces have very few industries. Therefore, there is a severe imbalance in the industrial sector too. Compared to the Western Province, most of other regions can be identified relatively as backward regions in terms of industries. 
Table 4

Regional Distribution of Industrial Enterprises in Sri Lanka

\begin{tabular}{|l|c|c|}
\hline \multicolumn{1}{|c|}{ Provinces } & $1999(\%)$ & $2001(\%)$ \\
\hline Western & $\mathbf{8 0 . 9}$ & $\mathbf{8 0}$ \\
\hline Central & 4.5 & 4.6 \\
\hline Southern & 4.9 & 4.9 \\
\hline North Western & 5.34 & 5.5 \\
\hline North Central & 0.7 & 1.1 \\
\hline Uva & 1.1 & 1.2 \\
\hline Sabaragamuwa & 1.7 & 1.7 \\
\hline Northern & 0.08 & 0.15 \\
\hline Eastern & 0.5 & 0.6 \\
\hline
\end{tabular}

Source: - Central Bank of Sri Lanka, Annual Report-2001

\section{Poverty}

Consumption poverty as well as human poverty is higher in Sri Lanka (UNDP, 1998, Karunanayake, 2001). Consumption poverty remains at much higher level than human poverty. Consumption poverty is the inability to achieve a certain minimum standard in consumption. Considering the spatial pattern of consumption poverty in Sri Lanka, according to the Household and Consumption Survey of 1995 /1996 of the Department of Censes and Statistics the Western Province records the lowest poverty level while other provinces record higher levels of consumption poverty. With regard to human poverty the Western Province reports the lowest value of poverty according to figure 1 . Other Provinces such as the Sabaragamuwa, Central, Uva and the North-Western Provinces have the higher level of poverty. Over $23 \%$ of the population in these regions is experiencing social and economic deprivation. Human Development Report in 1998 pointed out the main reason for the high level of human poverty in those regions is the luck of adequate social amenities such as water, sanitation, and electricity. However, it is clear that consumption and human poverty remain at a higher level in most of the provinces in Sri Lanka. 


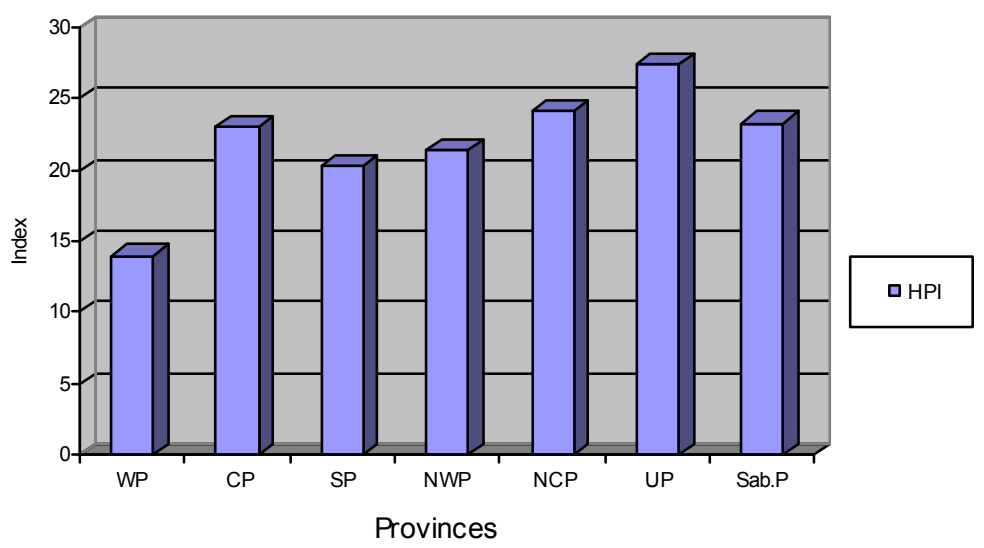

Source:-National Human Development Report, 1998

Figure-1

\section{Infrastructural Facilities}

The absence of adequate infrastructure facilities also is one of the major barriers for regional development in Sri Lanka. The pattern of major investment, industries, commerce and economic activities are highly influenced by the availability of physical infrastructure. Especially, the road network can play an important role in linking regions in terms of movement of people and the products. Therefore, every regional plan should pay attention to expand physical infrastructure to promote the economic growth.

The coverage and quality of the road network are the major constrain on the economic production in many regions in Sri Lanka. According to the Table 5 highest concentration of road also can be seen in the Western Province. It has become a great advantage to the development in the Wet Zone. Especially in the Dry Zone areas the transport facilities are not sufficient. The insufficient transport network inhibits the access to production input, increases the production costs and restricts access to markets. 
Table 5

Regional Pattern of Availability of Roads in Sri Lanka- 1995

\begin{tabular}{|l|c|c|}
\hline Province & $\begin{array}{c}\text { Road density } \\
\text { (per sq.km) }\end{array}$ & Rank \\
\hline Western & $\mathbf{0 . 9 6}$ & $\mathbf{1}$ \\
\hline Central & 0.74 & 3 \\
\hline Southern & 0.54 & 4 \\
\hline $\begin{array}{l}\text { Sabaragam } \\
\text { uwa }\end{array}$ & 0.45 & 5 \\
\hline $\begin{array}{l}\text { North } \\
\text { Western }\end{array}$ & 0.44 & 6 \\
\hline $\begin{array}{l}\text { Uva } \\
\text { North } \\
\text { Central }\end{array}$ & 0.34 & 7 \\
\hline Northern & 0.26 & 8 \\
\hline Eastern & 0.18 & 9 \\
\hline
\end{tabular}

Source - Human Development Report, 1998

Table 6

Disparities in Infrastructure by Provinces in Sri Lanka-1998

\begin{tabular}{|l|c|c|c|c|c|}
\hline Provinces & $\begin{array}{c}\text { Communi } \\
\text { cation } \\
\text { (Rank) }\end{array}$ & $\begin{array}{c}\text { Electricity } \\
\text { (Rank) }\end{array}$ & $\begin{array}{c}\text { Safe water } \\
\text { (Rank) }\end{array}$ & $\begin{array}{c}\text { Sanitation } \\
\text { (Rank) }\end{array}$ & $\begin{array}{c}\text { Aggregate } \\
\text { Rank }\end{array}$ \\
\hline Western & 1 & 1 & 1 & 1 & 1 \\
\hline Central & 2 & 3 & 2 & 4 & 2 \\
\hline Southern & 3 & 2 & 5 & 2 & 3 \\
\hline Northern & 9 & 9 & - & - & - \\
\hline Eastern & 8 & 8 & - & - & - \\
\hline $\begin{array}{l}\text { North } \\
\text { Western }\end{array}$ & 7 & 4 & 4 & 5 & 7 \\
\hline $\begin{array}{l}\text { North } \\
\text { Central }\end{array}$ & 6 & 5 & 7 & 6 & 6 \\
\hline Uva & 4 & 6 & 6 & 7 & 4 \\
\hline $\begin{array}{l}\text { Sabaraga } \\
\text { muwa }\end{array}$ & 5 & 7 & 3 & 3 & 5 \\
\hline
\end{tabular}

Source: - Human Development Report, 1998

Other infrastructure facilities also are highly concentrated in the Western Province while other provinces have less concentration. All other facilities such as electricity, safe water and sanitation also are highly concentrated in the Western Province (Table 6). North-Western, North Central, Uva and Sabaragamuwa are poor provinces in terms of the physical infrastructure too. 


\section{Human Development}

Human development index is the best measurement to understand the socioeconomic development of a country or a region. As shown by the UNDP (1998), human development has become the crowing achievement of a country that successfully combines high social development with strong equitable economic growth. Although Sri Lanka has achieved a considerable level of human development in international context its benefits are unevenly distributed at the regional level. According to the Human Development Report of 1998, the province wise pattern of human development achievement shows the existence of a considerable variation in regions.

Life expectancy, education and standard of living are the three variables consisted by the concept of human development. According to Table 7 the Western Province has achieved the highest level of human development while Sabaragamuwa, Southern, Central and Uva Provinces confirm the major regional disparities. There is a large gap between the highest and the lowest indexes. It is about 0.15 and confirms the high degree of province level disparities in human development.

Table-7

The Regional Pattern of Human Development in Sri Lanka - 1994

\begin{tabular}{|l|c|c|c|c|c|}
\hline \multicolumn{1}{|c|}{ Province } & Life Expectancy Index & $\begin{array}{c}\text { Education } \\
\text { Index }\end{array}$ & G.D.P & H.D.I & $\begin{array}{l}\text { Rank of } \\
\text { H.D.I }\end{array}$ \\
\hline Western & 0.833 & 0.759 & 0.998 & 0.864 & 1 \\
\hline Central & 0.772 & 0.771 & 0.697 & 0.727 & 6 \\
\hline Southern & 0.928 & 0.736 & 0,519 & 0.728 & 5 \\
\hline North Western & 0.875 & 0.760 & 0.778 & 0.804 & 3 \\
\hline North Central & 0.842 & & & & 2 \\
\hline Uva & 0.842 & 0.977 & 0.977 & 0.859 & 7 \\
\hline Sabaragamuwa & 0.942 & 0.708 & 0.565 & 0.705 & \\
\hline Sri Lanka & 0.942 & 0.734 & 0.562 & 0.746 & 4 \\
\hline
\end{tabular}

G.D.P. - Gross Domestic Product.

H.D.I. - Human Development Index.

Source- National Human Development Report, 1998 
1994

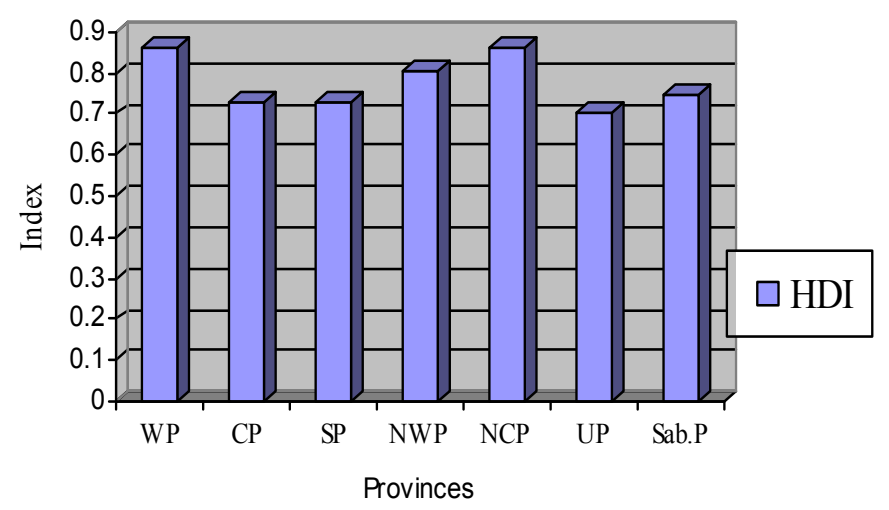

Source- National Human Development Report, 1998

Figure 2

In terms of life expectancy, all provinces have achieved relatively high level. It is due to the universal access to public health care, high level of education attainment and poverty alleviation and social welfare programs launched in the last 2 decades. All provinces perform high level of education enhanced by the state education policies, which support free primary and secondary education.

Standard of living is the third dimension of human development. It is closely related to the level of per capita of a region. According to the table there is a wide disparity in GDP per capita between regions. The Western Province has the highest GDP per capita index. It is about 0.998 . The lowest value that is 0.519 belongs to the Southern Province (UNDP, 1998). Central Province, Uva Province and Sabaragamuwa Province also have relatively lowest indexes confirming, the regional disparities in per capita GDP. This difference in living standard among provinces is the major factor for significant variation in human development. Differences in living standard are mainly the result of varying economic performance and income levels in the provinces.

All the above indicators provides a clear picture of regional growth pattern of Sri Lanka. There is on doubt that even after the independent Western Province as the core dominates the country. Most of the other peripheral regions are stagnating or experiencing slow growth. Analyzing he development indicators such as Average Annual Growth Rate of GDP, per capita GDP, trends in per capita Gross Regional Product, the contribution of each province to the GDP and to the manufacturing sector, Aggregate Infrastructural Index and HDI, Wanasinghe (2001) has attempted to classify peripheral regions of Sri Lanka as follows.

1. Fast growing periphery

- Southern and Central Province

2. Moderately fast growing periphery - North Central and North Western Province

3. Slow growing periphery - a. Sabaragamuwa and Vua Province

- b. Northern and Eastern Province (on going war has effected the development ) 


\section{Conclusion}

It is evident from the discussion presented in this paper though, Sri Lanka has experience in regional development planning and implementation in the past several decades Sri Lanka still has a considerable variation in regional growth and development. These regional differences are further articulated by the dynamic nature of the core of the country. As mentioned above the core region has distinct advantages over the other regions aided by a number of spatial policies of the government that have had direct and indirect beneficial effects on the core region. It implies that the past regional development policies have been clearly insufficient to promote the growth at the regional level. The absence of adequate comprehensive development policies and programs for sub-national regions in the periphery of the country has helped the following major issues which are well marked to day in spatial development in Sri Lanka.

- Growing polarization between the Colombo Metropolitan Region

- $\quad$ Lagging and slow growth of some regions

- $\quad$ Spatially imbalanced growth patterns

Regional development is an integral part of overall national development of a country. In the context of Sri Lanka, despite its small size, it is a country of great diversity; geographically, economically and culturally. Each sub-national region has its own regional identity and the development problems faced by different regions as well as their development potentials are also different. This diversity can be used as a positive factor that can be harnessed for development in competitive and innovative ways. Therefore, to provide a solution for the above issues that exist today in the country, rethinking of development policies and strategies which realize development potentials in each region and enhance its comparative advantages is essential.

\section{References}

Abeygunawardana, C.1987. Administrative Capacity for Regional Planning of District Level: The Sri Lankan Experience 1970-1980. Sri Lankan Institute of Development Administration.

Dangalle, N. 2002. Regional Development Experience of Sri Lanka in Narman, Anders \& Karunanayake, Kamal (ed). Towards a New Regional and Local Development Research Agenda. Department of Human and Economic Geography, Goteborg University, and Center for Development Studies, University of Kelaniya, Sri Lanka.

Dangalle, N. 2005. Spatial Disparities in Development in Sri Lanka in Karunanayake, M.M. \&Narman, Anders(ed). Regional Development In Sri Lanka: Resetting the Agenda. University of Sri Jayawardenepura, Sri Lanka.

Deheragoda, C.K.M. et al. 1992. Urban Growth in Sri Lanka; Implications for Regional Development. UNCRD Working Paper No. 92-4. United Nations Centre for Regional Development. Nagoya. Japan.

Department of Census and Statistics. Ministry of Finance and Planning, Statistical Abstract. 1999. 
Department of Census and Statistics. Ministry of Finance and Planning. Statistical Abstract.2000.

Friedmann, John. 1970. Regional Development Policy: A Case Study on Venezuela. M.I.T. Press. London.

Glasson, John.1974. An Introduction to Regional Development Planning: Concept Theory and Practice. Hutchinson and Sons Ltd. London.

Goonerathne, Wilbert. 2001. Rethinking Sri Lanka's Regional Development: Concept, Policies and Institutions in Karunanayake, M.M. (ed). Poverty, Spatial Imbalance and Regional Development in Sri Lanka: Policies and Issues. Department of Geography, University of Sri Jayawardanepura, Sri Lanka.

Karunanayake, M.M. 2001. Introduction in Karunanayake, M.M. (ed). Poverty, Spatial Imbalance and Regional Development in Sri Lanka: Policies and Issues. Department of Geography, University of Sri Jayawardanepura, Sri Lanka.

UNDP.1998. National Human Development Report-Sri Lanka-1998. Regional Dimensions of Human Development.

Wanasinghe, Y.A.D.S, 2001. Regional Imbalances in Sri Lanka: A Critique of Regional Development Policies and Strategies in Karunanayake, M.M. (ed). People, Space and Resources: Perspective on Development Issues in Rural Sri Lanka. Department of Geography, University of Sri Jayawardanepura, Sri Lanka. 